\title{
Pigtail Protruding out of the Gastric Wall
}

\author{
Sho Kitagawa Haruna Kawajiri Shori Ishikawa \\ Department of Gastroenterology, Sapporo Kosei General Hospital, Sapporo, Japan
}

\section{Keywords}

Endoscopic retrograde cholangiopancreatography · Plastic stent . Upper gastrointestinal tract

\section{Pigtail saindo da parede gástrica}

\section{Palavras Chave}

Colangiopancreatografia retrógrada endoscópica.

Prótese plástica · Trato digestivo superior

Endoscopic treatment of pancreatic pseudocyst has experienced great progress in recent years, and it is becoming the first-line treatment in many cases $[1,2]$. Nowadays, endoscopic ultrasound-guided drainage has played a central role as a minimally invasive technique $[3,4]$. The transpapillary approach could be an alternative choice for endoscopic treatment of pancreatic pseudocyst, if transmural drainage is not feasible due to distance or is contraindicated [5]. This report describes an unusual complication of transpapillary stenting in the management of pancreatic pseudocyst.

A 69-year-old man, who had been diagnosed with locally advanced pancreatic ductal adenocarcinoma with marked atrophy of upstream pancreas, presented with

karger@karger.com www.karger.com/pjg

Karger"
(C) 2021 Sociedade Portuguesa de Gastrenterologia. Published by S. Karger AG, Basel

This is an Open Access article licensed under the Creative Commons Attribution-NonCommercial-4.0 International License (CC BY-NC) (http://www.karger.com/Services/OpenAccessLicense), applicable to the online version of the article only. Usage and distribution for commercial purposes requires written permission. slight epigastric discomfort and fever. Computed tomography revealed a $3.5-\mathrm{cm}$ pseudocyst associated with the pancreatic body carcinoma and engorgement of collateral veins (Fig. 1), and we considered that the pseudocyst might be the cause of symptoms. Although the patient had received intravenous ceftriaxone for 3 days, he showed no sign of improvement. Taking the risk of bleeding from the collateral veins into account, we performed endoscopic transpapillary drainage of the pseudocyst instead of endoscopic ultrasound-guided drainage. A 7-Fr, $10-\mathrm{cm}$ double pigtail stent, which was considered to be associated with less migration and perforation, was successfully placed transpapillary (Fig. 2), and purulent discharge came out through the stent. The patient's symptoms improved immediately after the drainage, and he was discharged without any sequelae. Nineteen days later, upper gastrointestinal endoscopy was performed to investigate the cause of anemia. Unexpectedly, a pigtail was found to protrude into the gastric lumen with formation of a fistula between the pseudocyst and the stomach (Fig. 3). Transient bleeding from the fistula was presumed to be the cause of anemia; however, no further development of anemia was observed. Although the double pigtail stent was not removed, no problem related to the stent was observed until he died from the pancreatic ductal adenocarcinoma 5 months later.
Correspondence to:

Sho Kitagawa, bossa0405@yahoo.co.jp 


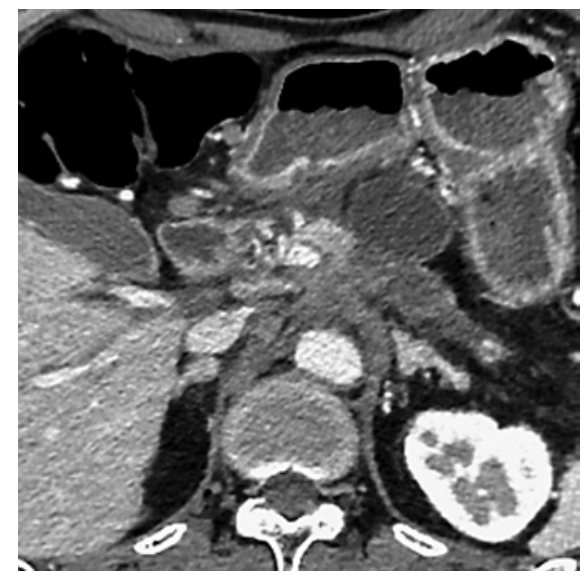

Fig. 1. Computed tomography showed a pancreatic pseudocyst associated with locally advanced pancreatic body carcinoma.

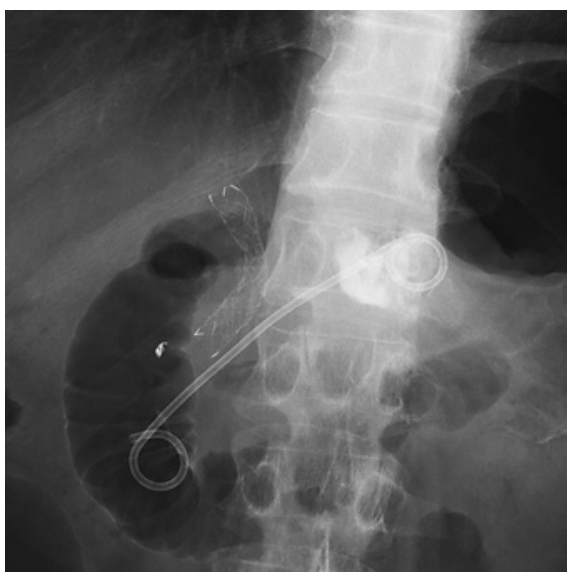

Fig. 2. Endoscopic transpapillary drainage was performed using a 7-Fr double pigtail.

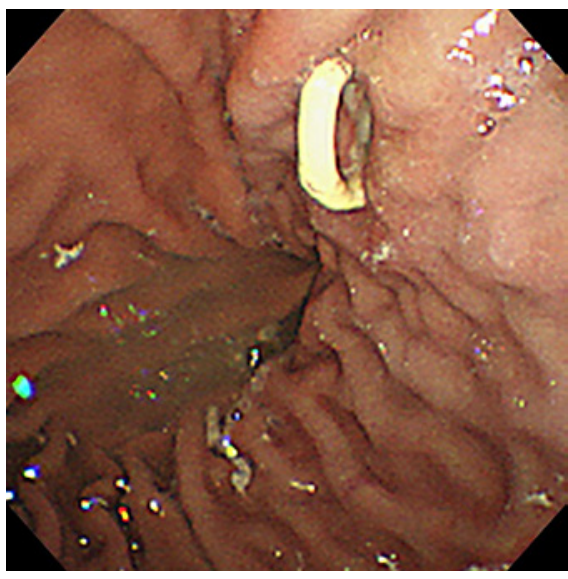

Fig. 3. A pigtail of the stent was found to protrude into the gastric lumen.
We have considered that the pigtail in the duodenum prevents migration and that the pigtail in the pseudocyst avoids the risk of perforation. Although uncommon, clinicians should consider the potential risk associated with the pigtail when using a double pigtail stent for transpapillary drainage of pancreatic pseudocyst.

\section{Statement of Ethics}

Patient consent was obtained for the publication of this report, including images.

\section{References}

1 Varadarajulu S, Wilcox CM, Latif S, Phadnis M, Christein JD. Management of pancreatic fluid collections: a changing of the guard from surgery to endoscopy. Am Surg. 2011 Dec; 77(12):1650-5.

2 Varadarajulu S, Bang JY, Sutton BS, Trevino JM, Christein JD, Wilcox CM. Equal efficacy of endoscopic and surgical cystogastrostomy for pancreatic pseudocyst drainage in a randomized trial. Gastroenterology. 2013 Sep; 145(3):583-90.e1.

\section{Conflict of Interest Statement}

The authors have no conflicts of interest to declare.

Funding Sources

There has been no financial support for this work.

\section{Author Contributions}

S. Kitagawa is the article guarantor and wrote the manuscript. H. Kawajiri and S. Ishikawa reviewed the literature.
3 Varadarajulu S, Christein JD, Tamhane A, Drelichman ER, Wilcox CM. Prospective randomized trial comparing EUS and EGD for transmural drainage of pancreatic pseudocysts (with videos). Gastrointest Endosc. 2008 Dec;68(6):1102-11.
4 Park DH, Lee SS, Moon SH, Choi SY, Jung SW, Seo DW, et al. Endoscopic ultrasoundguided versus conventional transmural drainage for pancreatic pseudocysts: a prospective randomized trial. Endoscopy. 2009 Oct; 41(10):842-8.

5 Goyal J, Ramesh J. Endoscopic management of peripancreatic fluid collections. Frontline Gastroenterol. 2015 Jul;6(3):199-207. 